\title{
Left Ventricular Noncompaction 7
}

National Cancer Institute

\section{Source}

National Cancer Institute. Left Ventricular Noncompaction 7. NCI Thesaurus. Code C157266.

An autosomal dominant sub-type of left ventricular noncompaction syndrome caused by heterozygous mutation(s) of the M1B1 gene, encoding E3 ubiquitin-protein ligase MIB1. 